\title{
Corticosteroid regulation of amiloride-sensitive sodium-channel subunit mRNA expression in mouse kidney
}

\author{
P MacDonald, S MacKenzie, L E Ramage, J R Seckl and \\ R W Brown
}

Molecular Medicine Centre, Western General Hospital, Edinburgh EH4 2XU, UK

(Requests for offprints should be addressed to R W Brown; Email rbrown@srv0.med.ed.ac.uk)

\begin{abstract}
Corticosteroid control of distal nephron sodium handling, particularly through the amiloride-sensitive sodium channel $(\mathrm{ENaC})$, has a key role in blood pressure regulation. The mechanisms regulating $\mathrm{ENaC}$ activity remain unclear. Despite the generation of useful mouse models of disorders of electrolyte balance and blood pressure, there has been little study of distal nephron sodium handling in this species. To investigate how corticosteroids regulate $\mathrm{ENaC}$ activity we isolated cDNA for the three mouse $\mathrm{ENaC}$ subunits $(\alpha, \beta$ and $\gamma)$, enabling their quantitation by competitive PCR and in situ hybridisation. Kidneys were analysed from mice 6 days after adrenalectomy or placement of osmotic mini-pumps delivering aldosterone (50 $\mu \mathrm{g} / \mathrm{kg}$ per day), dexamethasone $(100 \mu \mathrm{g} / \mathrm{kg}$ per day), spironolactone $(20 \mathrm{mg} / \mathrm{kg}$ per day) or vehicle alone (controls). In controls, renal ENaC $\alpha$ mRNA exceeded $\beta$ or $\gamma$ by approximately $1 \cdot 75-$ to $2 \cdot 8$-fold. All subunit mRNAs were expressed in renal cortex and outer medulla, where the pattern of expression was fully consistent with localisation in collecting duct, whereas the distribution in
\end{abstract}

cortex suggested expression extended beyond the collecting duct into adjacent distal tubule. Subunit mRNA expression decreased from cortex to outer medulla, with a gradual reduction in $\beta$ and $\gamma$, and $\mathrm{ENaC} \alpha$ decreased sharply $(\sim 50 \%)$ across the outer medulla. Expression of $\mathrm{ENaC} \beta$ and $\gamma$ (but not $\alpha$ ) extended into inner medulla, suggesting the potential for inner medulla collecting duct cation channels in which at least $\mathrm{ENaC} \beta \gamma$ participate. Aldosterone significantly increased $\mathrm{ENaC}$ subunit expression; the other treatments had little effect. Aldosterone caused a 1.9- to 3.5-fold increase in $\mathrm{ENaCa}$ (particularly marked in outer medullary collecting duct), but changes for $\beta$ and $\gamma$ were minor and limited to the cortex. The results raise the possibility that medullary $\mathrm{ENaC} \alpha$ upregulation by aldosterone will create more favourable subunit stoichiometry leading to a more substantial increase in $\mathrm{ENaC}$ activity. In cortex, such a mechanism is unlikely to have a major role.

Journal of Endocrinology (2000) 165, 25-37

\section{Introduction}

Corticosteroid hormones, which include the mineralocorticoid aldosterone and the glucocorticoids cortisol and corticosterone, have key roles in the regulation of body sodium balance, and thus directly determine body fluid balance and blood pressure. In particular, corticosteroids critically regulate renal sodium handling in the distal nephron. A major effector of this corticosteroid action is the epithelial sodium channel $(\mathrm{ENaC})$, which comprises three different subunits. The encoding genes have recently been cloned (Canessa et al. 1994). Mutations in ENaC subunits cause human diseases in which the channels are either overactive, causing excess sodium retention and hypertension (Liddle's syndrome (Hansson et al. 1995)), or underactive, causing sodium and water loss, low blood pressure and difficulty clearing lung fluid neonatally (autosomal recessive pseudohypoaldosteronism (PHA-1)
(Chang et al. 1996)). Mice homozygous for targeted disruption (knockout) of $\mathrm{ENaC} \alpha$ die neonatally from accumulation of lung fluid; partial restoration of $\mathrm{ENaC} \alpha$ expression rescues such mice from pulmonary problems but, neonatally, they develop renal sodium and fluid wasting, modelling human PHA-1 (Hummler et al. 1997).

The mechanism by which aldosterone-induced proteins increase the apical amiloride-sensitive sodium conductance is not understood (Grunder \& Rossier 1997). Some research on amphibians suggests aldosterone upregulates sodium conductance, without increasing the number of channels, by increasing the open probability $(P \mathrm{O})$ of existing apical channels (Kemendy et al. 1992, Vallet et al. 1997). In contrast, patch clamp studies in rat cortical collecting tubules suggest that aldosterone increases the number of channels per patch without any effect on $P$, indicating that the production and apical insertion of new 
Table 1 Experimental treatment groups

\begin{tabular}{|c|c|c|}
\hline & Mini-pump contents & Drug-delivery rate \\
\hline \multicolumn{3}{|l|}{ Group } \\
\hline 1: Adrenalectomy & Vehicle A only & - \\
\hline 2: Dexamethasone & Dexamethasone/vehicle A & $100 \mu \mathrm{g} / \mathrm{kg}$ per day \\
\hline 3: Aldosterone & Aldosterone/vehicle A & $50 \mu \mathrm{g} / \mathrm{kg}$ per day \\
\hline 4: Spironolactone & Spironolactone/vehicle B & $20 \mathrm{mg} / \mathrm{kg}$ per day \\
\hline 5: Control A & Vehicle $A^{*}$ only & - \\
\hline 6: Control B & Vehicle $\mathrm{B}^{*}$ only & - \\
\hline
\end{tabular}

channels may be involved (Pacha et al. 1993). More recently, the elucidation of the basis of Liddle's syndrome has demonstrated an equilibrium between an intracellular pool of $\mathrm{ENaC}$ subunits and the formation of active channels in the apical membrane. ENaC subunits bearing Liddle's mutations partition in increased numbers to the apical collecting duct membrane (Snyder et al. 1995, Grunder \& Rossier 1997). Thus an increased apical amiloride-sensitive sodium conductance could arise from (i) increased new synthesis of channel subunits, (ii) increased partitioning of presynthesised subunits to the apical membrane or (iii) an increase in the $P$ o of channels already in the apical membrane. It may be that short-term upregulation of apical amiloride-sensitive sodium conductance by aldosterone can be achieved solely through mechanisms (ii) and (iii) and already synthesised sodiumchannel subunits, whereas chronic maintenance of greater conductance may require increased $\mathrm{ENaC}$ subunit transcription (Garty \& Palmer 1997, Grunder \& Rossier 1997). Experiments in vitro and in cell culture show convincingly that both short-term and chronic increases in conductance after mineralocorticoid treatment require transcription, as they are abolished by transcription inhibitors. However, the nature of the genes transcribed and the extent to which transcriptional regulation of $\mathrm{ENaC}$ subunits is involved are unclear (Garty \& Palmer 1997). Now that the $\mathrm{ENaC}$ subunits have been cloned in several species, this is amenable to study. There has, however, been little work on the subject in mouse, although the recent production of mice with partial rescue from $\mathrm{ENaC} \alpha$ knockout, having a phenotype resembling human PHA-1, illustrates the usefulness of work on this species in modelling human renal sodium handling and its disorders (Hummler et al. 1997).

To investigate how corticosteroids regulate $\mathrm{ENaC}$ activity and expression in the nephron, we have isolated cDNA for the three mouse ENaC subunits and used them to study the distribution of $\mathrm{ENaC}$ subunit expression in mouse kidney. By using manipulations chronically affecting corticosteroid status, we then assessed the extent to which transcriptional regulation mediated the corticosteroid effects on ENaC.

\section{Materials and Methods}

\section{Materials}

Steroids, propylene glycol, dimethyl sulphoxide and reagent and molecular biology grade chemicals were purchased from Sigma Chemical Company (Poole, Dorset, UK), $1 \mathrm{~kb}$ ladder DNA size markers and synthesised oligonucleotides were purchased from Life Technologies/ Gibco (Paisley, Renfrewshire, UK), ALZET 1007D osmotic mini-pumps and mice were purchased from Charles River UK (Margate, Kent, UK), and ${ }^{35}$ S[UTP] was purchased from Amersham International (Little Chalfont, Bucks, UK).

\section{Animal treatment, tissue handling, and RNA isolation}

Thirty-six 8-week-old male C57BL/6J mice, 23.5-25 g weight (no significant group weight differences), were segregated into six groups of six animals per group, caged in pairs within their own group. Table 1 gives details of the six groups. All mice had ALZET 1007D osmotic minipumps (pre-loaded with treatment or vehicle, and preweighed) implanted subcutaneously; group 1 also had bilateral adrenalectomy. These operations were performed under halothane anaesthesia.

Mice in group 2 received dexamethasone in a dosage that causes modest glucocorticoid excess and suppression of the hypothalamic-pituitary-adrenal (HPA) axis and corticosterone concentrations (Almeida et al. 1997), and thus 'substitutes' dexamethasone for corticosterone. Group 3 received aldosterone; previous studies using high doses, and our preliminary work, indicated the aldosterone dosage used in adrenal-intact animals would cause an approximately threefold increase in mean plasma aldosterone concentrations. In group 4, spironolactone was used to block mineralocorticoid receptor-mediated effects. Thus an effect common to spironolactone and adrenalectomy groups indicated loss of mineralocorticoid receptor activation as the expected mechanism.

All mice had free access to normal diet and water (with saline additionally available to adrenalectomised mice). On the 6th day after pump implantation, animals were killed 
by cervical dislocation and both kidneys were removed, immediately frozen on a bed of powdered dry ice and stored at $-80^{\circ} \mathrm{C}$. Total RNA was then carefully extracted from one whole kidney from each animal, following the method of Chomczynski \& Sacchi (1987). RNA concentration was determined spectrophotometrically and $10 \mu \mathrm{g}$ was resolved by denaturing (formamide/formaldehyde) agarose electrophoresis to inspect for degradation (which was absent in all cases). The other kidney was used for in situ hybridisation studies.

\section{Plasma and urine specimens and assays}

Plasma renin activity, plasma aldosterone, corticosterone and urine electrolyte measurements were performed on samples removed on cardiac and bladder puncture rapidly after killing by cervical dislocation. Blood samples were spun; plasma was removed, put on ice and rapidly stored at $-20{ }^{\circ} \mathrm{C}$. Aliquots of plasma for renin assay were thawed and then immediately added to buffer that stabilised plasma renin activity. Renin activity was then assayed as previously described (Millar et al. 1980), yielding results expressed in nanograms angiotensin I generated per millitre per hour. Aldosterone was assayed by ${ }^{125}$ I-RIA (DPC, Los Angeles, CA, USA) and corticosterone as previously described (Kotelevtsev et al. 1997).

\section{Isolating partial cDNAs of mouse amiloride-sensitive sodium-channel subunits}

PCR primers were designed based on regions that were conserved for each subunit, but which diverged widely between the rat subunits. These primers were then used in RT-PCR with cDNA generated by reverse transcription of mouse kidney RNA (oligo-dT primed using Promega Reverse Transcription system (No. A3500) according to the manufacturer's instructions). RNA concentration was measured with accurate spectrophotometric quantitation, and sample uniformity confirmed by $18 \mathrm{~S}$ and $28 \mathrm{~S}$ band intensities on ethidium bromide agarose gels scanned using a FLA2000R Phosphor-Imager (Fuji Photo Film Ltd, Japan). Using this approach, partial cDNAs for the three mouse subunits were amplified as products of the expected size, isolated, and sequenced on both strands using solidphase sequencing (GATC GmbH, Konstanz, Germany). This confirmed them to be highly homologous with the sought subunit sequence in rat $(\%$ mouse-rat nucleotide sequence identity: $\mathrm{ENaC} \alpha=90 \cdot 2 \%$ (1015 bp equivalent to rat $\mathrm{ENaC \alpha}$ (accession X70497) bp 1463-2492), $\mathrm{ENaC} \beta=93.9 \%$ (775 bp equivalent to rat $\mathrm{ENaC} \alpha$ (X70497) bp 1170-1944) and $\mathrm{ENaC} \gamma=97 \cdot 2 \%$ (496 bp equivalent to rat $\mathrm{ENaC \gamma}$ (X77933) bp 1199-1694)).

\section{Production of single-stranded $R N A$ probes}

Using the mouse $\mathrm{ENaC}$ subunit sequence, primers were designed to amplify uniquely within the sequenced area of each subunit with primers including $5^{\prime}$ extensions con- taining phage polymerase consensus sites with top and bottom primer pairs incorporating $\mathrm{T} 3$ and $\mathrm{T} 7$ sites, respectively. PCR was then performed using $5 \mu \mathrm{l}$ of a $1: 20$ dilution (in $1 \times$ PCR buffer) mouse kidney cDNA (generated as above) as template, which was denatured, at $96{ }^{\circ} \mathrm{C}$ for $3 \mathrm{~min}$ and placed on ice; $15 \mathrm{pmol}$ each primer, $50 \mu \mathrm{mol} \mathrm{dNTP}$ and $2 \mathrm{U}$ Taq Polymerase were then added, to a final volume of $50 \mu \mathrm{l}$ in $1 \times$ PCR buffer. Reactions were then placed into a thermal cycler (HBTR1; Hybaid, Teddington, Middx, UK) with the block held at $90{ }^{\circ} \mathrm{C}$ and the programme commenced: five cycles of $60 \mathrm{~s}$ at $95^{\circ} \mathrm{C}, 60 \mathrm{~s}$ at $55^{\circ} \mathrm{C}$ and $120 \mathrm{~s}$ at $72{ }^{\circ} \mathrm{C}$, followed by 30 cycles of $60 \mathrm{~s}$ at $95^{\circ} \mathrm{C}$ and $120 \mathrm{~s}$ at $72{ }^{\circ} \mathrm{C}$ and, finally, $10 \mathrm{~min}$ at $72^{\circ} \mathrm{C}$. PCR products were thus amplified and then purified (across Qiaquik columns (Qiagen, Crawley, West Sussex, UK)) with T3 and T7 sites flanking inserts of mouse $\mathrm{ENaC}$ subunits corresponding to regions from rat $\mathrm{ENaC}$ subunits as detailed in Table 2. These purified products then allowed production of single-stranded $\left[{ }^{35} \mathrm{~S}\right] \mathrm{UTP}$-labelled RNA probes of the corresponding inserts for in situ hybridisation as described elsewhere (Brown et al. 1996) using the required DNA-dependent RNA phage polymerase (T3-sense, T7-antisense).

\section{In situ hybridisation}

For in situ hybridisation, cryostat sections $(10 \mu \mathrm{m})$ were cut from intact kidneys that had been stored at $-80^{\circ} \mathrm{C}$, taken from mice of all treatment groups. Sections were thawmounted onto 3-amino propyl triethoxysilane-coated slides and stored at $-80{ }^{\circ} \mathrm{C}$. For in situ hybridisation (Wilkinson 1992, Brown et al. 1996), slides were taken from $-80{ }^{\circ} \mathrm{C}$ storage and processed through standard fixation and prehybridisation. Fixation involved serial immersion of slides in: ice-cold paraformaldehyde (10 min), twice for $5 \mathrm{~min}$ in PBS $\mathrm{pH} 7 \cdot 4,0 \cdot 5 \%$ acetic anhydride $-0 \cdot 1 \mathrm{M}$ triethanolamine $\mathrm{pH} 8$ (10 min), PBS (3 $\mathrm{min}), 70 \%$ ethanol ( $2 \mathrm{~min}$ ), $80 \%$ ethanol $(2 \mathrm{~min})$ and, finally, 95\% ethanol ( $2 \mathrm{~min})$. Slides were then air-dried (30 min) before storage $\left(-20^{\circ} \mathrm{C}\right)$ or prehybridisation by adding $200 \mu \mathrm{l}$ prehybridisation solution (see below) per slide and incubating at $50{ }^{\circ} \mathrm{C}$ for $2 \mathrm{~h}$ in boxes humidified by flooring with absorbent paper soaked in formamide box buffer $(50 \mathrm{ml}$, composed of $10 \mathrm{ml} 20 \times$ SSC, $15 \mathrm{ml}$ diethyl pyrocarbonate (DEPC)-treated water and $25 \mathrm{ml}$ formamide (standard grade); $20 \times$ SSC: for 5 litres, $876 \mathrm{~g}$ $\mathrm{NaCl}$ and $441 \mathrm{~g}$ trisodium citrate were dissolved, and the $\mathrm{pH}$ adjusted to $7 \cdot 4$ ). Prehybridisation solution was then tipped off the slides and replaced with $200 \mu \mathrm{l} /$ slide hybridisation solution (see below) containing $4 \times 10^{6}$ c.p.m./ slide denatured $\left[{ }^{35} \mathrm{~S}\right] \mathrm{UTP}-\mathrm{labelled} \mathrm{RNA}$ probe. Tissue sections were then replaced in humidified boxes and incubated for $12-14 \mathrm{~h}$ at $50{ }^{\circ} \mathrm{C}$, and then processed through washes/RNase A treatment (maximum stringency wash of $0 \cdot 1 \times \mathrm{SSC}$ at $\left.60{ }^{\circ} \mathrm{C}\right)$. After the washes, 


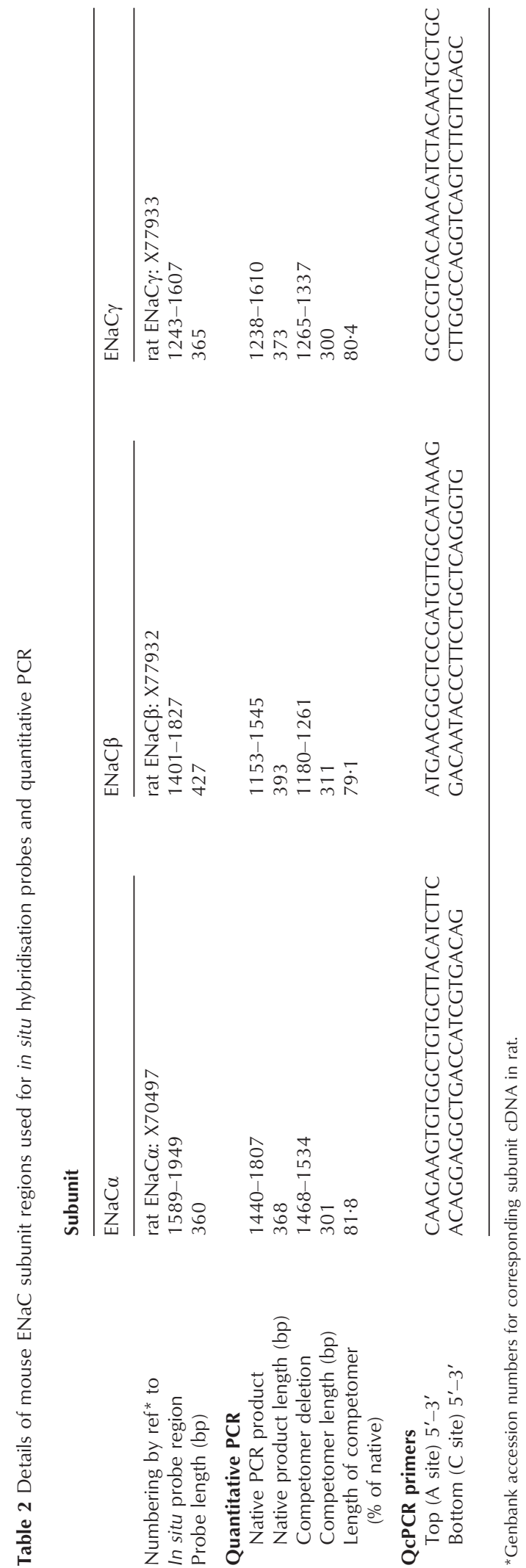


slides were dehydrated with serial 70-95\% ethanol washes, dried, and placed against $\beta$-Max Hyperfilm film (Amersham) for periods of $1-5$ days.

Solutions The prehybridisation solution contained 50\% deionised formamide (high quality grade) and 50\% $2 \times$ prehybridisation buffer $(10 \mathrm{ml}$, composed of $2.4 \mathrm{ml}$ $5 \mathrm{M} \mathrm{NaCl}, 200 \mu \mathrm{l} 1 \mathrm{M}$ Tris $\mathrm{pH} 7 \cdot 5,400 \mu \mathrm{l} 50 \times$ Denhardt's solution (Sigma D2532), $80 \mu \mathrm{l} 250 \mathrm{mM}$ EDTA, $1 \mathrm{ml} 10 \mathrm{mg} / \mathrm{ml}$ sonicated salmon sperm DNA, $40 \mu \mathrm{l} 50 \mathrm{mg} / \mathrm{ml}$ yeast tRNA and $5.88 \mathrm{ml}$ DEPC water).

The hybridisation solution contained 50\% deionised formamide (high quality grade) and 50\% $2 \times$ hybridisation buffer $(10 \mathrm{ml}$, composed of $2 \cdot 4 \mathrm{ml} 5 \mathrm{M} \mathrm{NaCl}, 200 \mu \mathrm{l} 1 \mathrm{M}$ Tris $\mathrm{pH} 7 \cdot 5,400 \mu \mathrm{l} 50 \times$ Denhardt's solution, $80 \mu \mathrm{l}$ $250 \mathrm{mM}$ EDTA, $200 \mu \mathrm{l} 10 \mathrm{mg} / \mathrm{ml}$ sonicated salmon sperm DNA, 2 g dextran sulphate, $40 \mu \mathrm{l} 50 \mathrm{mg} / \mathrm{ml}$ yeast tRNA and $6.68 \mathrm{ml}$ DEPC water), to which sufficient probe was added to achieve $20 \times 10^{6}$ c.p.m. $/ \mathrm{ml}$; this solution was mixed, heated to $80^{\circ} \mathrm{C}$ for $10 \mathrm{~min}$, cooled on ice before the addition of $10 \mu \mathrm{l} 1 \mathrm{M}$ dithiothreitol/ml, mixing, and use at $200 \mu \mathrm{l} /$ slide.

Slide development and analysis When a satisfactory range of autoradiographs was obtained, all slides were dipped in photographic emulsion (NTB-2, Kodak, UK) during one session, and exposed in a light-tight box for 17 days, before being developed (D19; Ilford, UK). Autoradiographic films were scanned on a high-resolution flatbed scanner, into tagged image format files then loaded into AIDA 2.0 image analysis software (Raytek Scientific Ltd, Sheffield, UK). Two-dimensional densitometric analysis was performed on total renal, cortical and medullary regions for each slide. Films were developed using invariant conditions and analysing the same background; sample regions on serial films showed a close linear correlation $(r>0.92)$ of region density with time of exposure for all three subunits. All in situ hybridisation sections were simultaneously dipped in emulsion, exposed for 17 days and developed as one batch, to minimise non-specific variation. Developed emulsion-dipped slides were analysed on a Zeiss Axioskop Microscope (Carl Zeiss, Welwyn Garden City, Herts, UK) with KS300 v3 Image analysis software (Carl Zeiss Vision, Eching, Germany), which enabled accurate computer-assisted counting of silver grains. All sections were analysed by determining grain counts/area over the most highly expressing areas (for all $\mathrm{ENaC}$ subunits, these corresponded to highly expressing tubular elements) in cortical and medullary zones, with four different such areas being counted per zone on each section. The background grain counts were subtracted for each section. Histological appearance and comparison between appearance on autoradiography and on emulsion-dipped slides for all three $\mathrm{ENaC}$ subunits on consecutive sections of the same kidney allowed clear definition of regions for analysis and differ- ences in distribution. Grain-count density was moderate, and fell in the linear range of the emulsion for both film densitometry and grain counts on dipped slides, indicating these parameters were proportional to incident radioactivity from the bound probe and underlying target mRNA.

\section{Production of shortened PCR competitor standards (short competomers) and quantitative competitive PCR (QcPCR)}

Using conventional PCR mutagenesis techniques (Clackson et al. 1991), PCR competitor standards of 300-311 bp bearing $67-82 \mathrm{bp}$ deletions near the $5^{\prime}$ end were generated for each mouse $\mathrm{ENaC}$ subunit. Bottom primers $(\mathrm{C})$ spanning an exon splice boundary (site $\mathrm{C}$ ) were used throughout First PCR, Second PCR and QcPCR assays. First PCR used a compound top primer $(\mathrm{A} / \mathrm{B})$ with sufficient $3^{\prime}$ sequence, $3^{\prime}$ of the desired deletion (site B), to anneal at $>55^{\circ} \mathrm{C}$, whereas the $5^{\prime}$ primer portion contained sequence $5^{\prime}$ to the desired deletion (site A). First PCR cycling parameters were as given above (for reactions generating $\mathrm{T} 3 / \mathrm{T} 7$ sites in products). Second PCR top primers (A) comprised just the site A portion of the First PCR (A/B) top primer, using a $1: 4000-1: 16000$ dilution of the first PCR product as template and conditions as above but with 35 cycles of $60 \mathrm{~s}$ at $95{ }^{\circ} \mathrm{C}, 60 \mathrm{~s}$ at $62{ }^{\circ} \mathrm{C}$ and $150 \mathrm{~s}$ at $72{ }^{\circ} \mathrm{C}$. These Second PCR reactions amplified up, as their only products, fragments (short competomers) from corresponding $\mathrm{ENaC}$ subunits between sites A and C (distance approximately $390 \mathrm{bp}$ ) containing deletions between sites $\mathrm{A}$ and $\mathrm{B}$ near their $5^{\prime}$ end (see Table 2). Using this method, short competomers were amplified, purified (across Qiaquik columns), spectrophotometrically quantified, and aliquots stored as standards for competitive PCR assay of the corresponding mouse $\mathrm{ENaC}$ subunit.

In QcPCR assays, the Second PCR reaction primers and conditions were used on a template of $5 \mu$ of a $1: 20$ dilution of sample cDNA (from reverse transcription, as above, but using random hexamer priming of $1 \mu \mathrm{g}$ sample total kidney RNA) and also incorporated $2 \mu \mathrm{l} 1 \times \mathrm{PCR}$ buffer containing precise amounts of the corresponding PCR short competomer standard. Thus QcPCR reactions would amplify products between sites $\mathrm{A}$ and $\mathrm{C}$ of the corresponding target subunit, and this resulted in amplification of native fragments of $\sim 390 \mathrm{bp}$ being co-amplified with competomer products being $\sim 75 \mathrm{bp}$ shorter. As can be seen from Table 2 these assays were designed to have almost identical competomer: native length ratios of $\sim 80 \%$. Next, $14 \mu \mathrm{l}$ PCR reaction product was run out on an ethidium-bromide-stained $1 \cdot 2 \%$ agarose gel (using $1 \mathrm{~kb}$ ladder (Gibco-BrL, Paisley, UK) for sizing). Table 2 gives $\mathrm{A}-$ and $\mathrm{C}$-site primer sequences. The $\mathrm{A} / \mathrm{B}$ compound primers used had the following sequences $\left(5^{\prime}-3^{\prime}\right)$ :

$\mathrm{ENaC} \alpha(\mathrm{A} / \mathrm{B})$ CAAGAAGTGTGGCTGTGCTTAC ATCTTCATAAACTGCAGGCTGCCTTC, 
$\mathrm{ENaC} \beta(\mathrm{A} / \mathrm{B})$ ATGAACGGCTCCGATGTTGCCA TAAAGGCAGTTGTGGCCACTACTT and ENaC $\gamma(A / B)$ GCCCGTCACAAACATCTACAATG CTGCAGTCAGCCTCTACCTCC.

PCR product was quantified by fluorescence of ethidium bromide on a FLA2000R Phosphor-Imager and subsequent two-dimensional analysis of the gel image using AIDA 2.0 software. Intensity data so derived were subjected to standard quantitative PCR analysis (see below) to calculate the concentration of the corresponding $\mathrm{ENaC}$ subunit in the assay sample. Briefly, raw intensity data were adjusted for proportionate size of the native and competomer product (Piatak et al. 1993), and the $\log _{10}$ (competomer : native product ratio) plotted against $\log _{10}$ (added competomer concentration). Figure 1 shows such a densitometric analysis of the products from a QcPCR assay for $\mathrm{ENaC} \alpha$ on one mouse kidney specimen. In the example illustrated in panel $\mathrm{A}$, the amount of added competomer decreases logarithmically going leftward across the lanes, and is accompanied by an increase in the native : competomer PCR product ratio; in panel $\mathrm{B}, \log _{10}$ of this ratio is plotted against $\log _{10}$ (added competomer concentration). Across this competomer concentration range, the point at which there are equal quantities of the products (point of equivalence, ratio $=1, \log _{10}($ ratio $)=0$ ) is crossed and the plot approximates to linear $(r=-0.982$ in this case). The point of equivalence can thus be estimated accurately. This allows a quantitative estimate of $\mathrm{ENaC \alpha}$ concentration in the reverse-transcribed sample, which is derived from $1 \mu \mathrm{g}$ total kidney RNA. In the example in Fig. 1, the point of equivalence, and thus the concentration of both competomer and $\mathrm{ENaC} \alpha \mathrm{cDNA}$, falls at $6 \cdot 3 \mathrm{amol} / \mu \mathrm{g}$ total RNA $\left(1 \mathrm{amol}=10^{-18} \mathrm{~mol}\right)$.

Such QcPCR assays were run for 35 cycles. The PCR assays for all subunits were validated as both freely competitive (Park et al. 1998) (linear amplification of native and competomer templates in PCR separately across 30-38 cycles and invariant competomer: native ratio across 30-38 cycles of PCR with both templates), and usefully quantitative (able to clearly detect a less than twofold change in native template quantity on samples to which the experimenter was blinded). The technique used is quantitative PCR rather than quantitative RT-PCR. The use of a phosphor-imager minimises error in quantifying intensity of ethidium bands. In our hands, the reproducibility of reverse transcription reactions, as above, is very high and has a coefficient of the variation ascribable to the RT reaction itself of $\sim 8 \%$, for reactions run concurrently using total RNA of similar source when the RNA samples have been prepared simultaneously. The resulting variability from reverse transcription is small, such that the error in the estimation of the mean of a group of six similar samples ascribable to the reverse transcription reaction is less than $4 \%$; we thus agree with others that factors such as expected pipetting errors in QcPCR may be a larger source of error (Hall et al. 1998). Hence, competitive PCR allows accurate relative quantitation of multiple transcripts in the same cDNA sample produced by reverse transcription with random (hexamer) primers, without the uncertainties about degradation in RNA competomers or over-representation of their incomplete transcripts (Zhang \& Byrne 1999) that can limit competitive RT-PCR accuracy.

\section{Statistical analysis}

The significance of differences between groups was tested by ANOVA and when the 'all effects' $F$ value was significant $(P<0 \cdot 05)$, post-hoc analysis of differences between individual groups was made with the NeumanKeuls test. Values are expressed as means \pm s.E. unless otherwise stated.

\section{Results}

There were no apparent physiological differences between the two control groups (groups 5 and 6), indicating that the two vehicles used in the experiment were equally inert for the parameters under study; therefore, in subsequent analyses, their results are presented in a combined control group (C). Some relevant physiological parameters of the treatment groups are given in Table 3: loss of corticosteroids with adrenalectomy (group 1); reduction of corticosterone with moderate dexamethasone dosage (group 2); a two- to threefold increase in aldosterone, and reduced plasma renin activity with moderate aldosterone dosage (group 3); increased aldosterone accompanied by high plasma renin activity with spironolactone treatment (group 4); this was similar to the effects of adrenalectomy, indicating effective mineralocorticoid antagonism.

\section{Quantitative competitive PCR (QcPCR)}

Figure 2 illustrates the quantitative estimates for the expression of $\mathrm{ENaC}$ subunits in the experimental groups (means \pm s.e.) derived from QcPCR analysis as in Fig. 1. There was a highly significant difference in the quantity of the three $\mathrm{ENaC}$ subunit mRNAs within a single sample with $\alpha>\gamma \approx \beta$ for all samples. In controls, $\alpha>\gamma$ by a mean 3.4-fold $(P<0 \cdot 0005,1 \cdot 95-5 \cdot 7$ ( \pm 1.96 s.E. $))$, and $\alpha>\beta$ by 4.9-fold $(P<0 \cdot 0005,1 \cdot 7-14 \cdot 1)$, whereas $\gamma \approx \beta$, with a $\gamma: \beta$ ratio of $1.46 \quad(P=$ non-significant, $0.55-3.9)$. Aldosterone treatment significantly upregulated $\mathrm{ENaC} \alpha$ mRNA expression, 3.5-fold (0.55 $\pm 0 \cdot 195$, mean \pm s.E. $\log _{10}$ increment) compared with adrenalectomy, and $4 \cdot 1$ fold $\left(0 \cdot 615 \pm 0 \cdot 302, \log _{10}\right)$ compared with spironolactone. In contrast, dexamethasone had no effect on the level of $\mathrm{ENaC} \alpha$ expression.

\section{In situ hybridisation}

In situ hybridisation allowed study of $\mathrm{ENaC}$ subunit mRNA expression in mouse kidney in detail (Figs 3-6), 


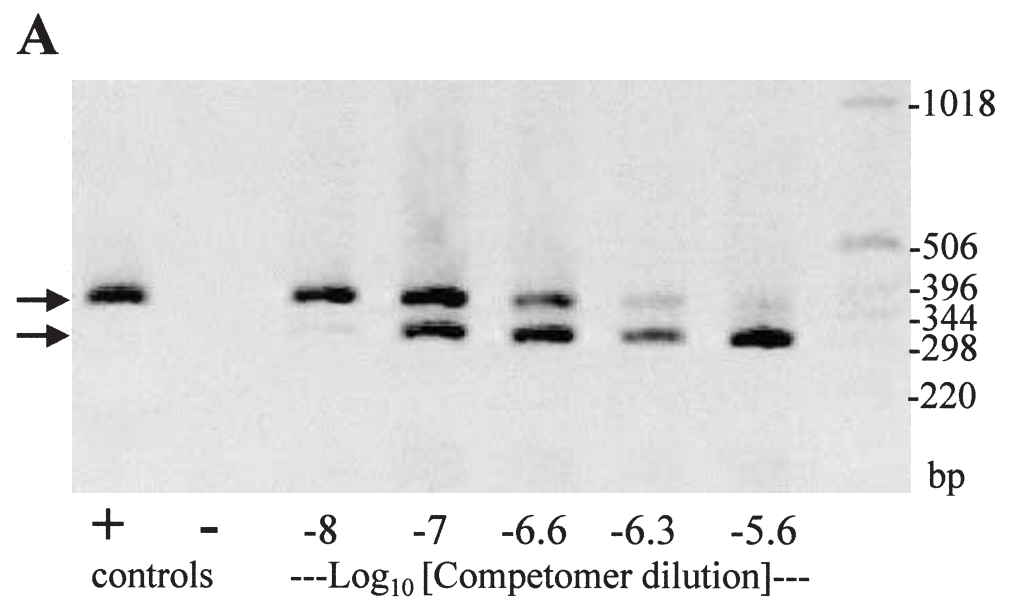

B

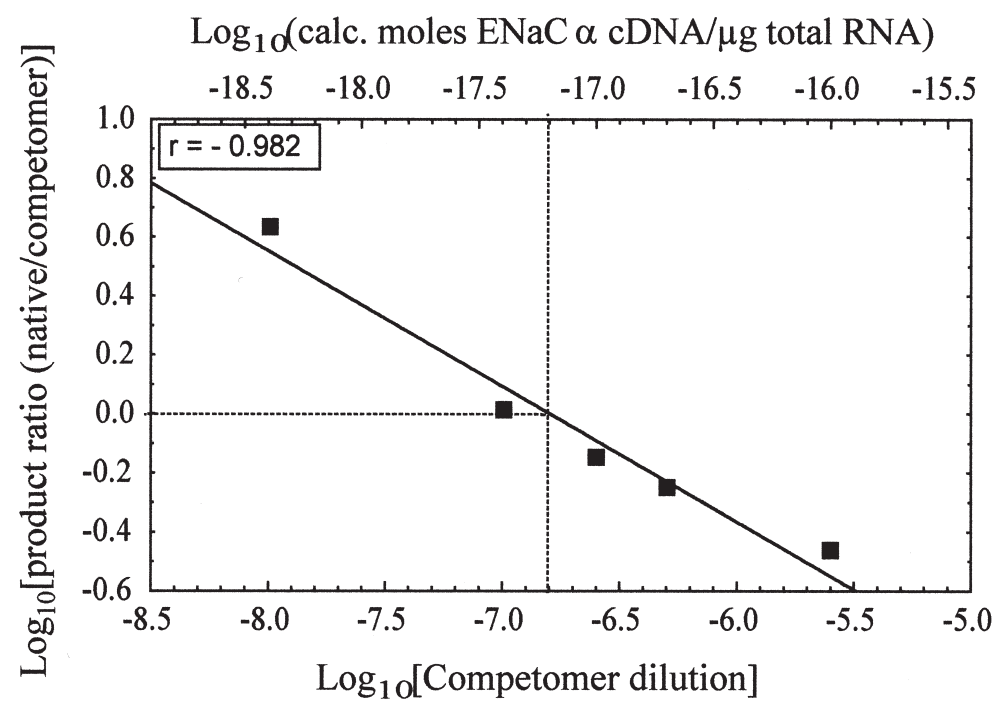

Figure 1 Example of quantitative competitive PCR (QcPCR) assay for mouse ENaC $\alpha$ on reverse-transcribed (RT) kidney cDNA. (A) Negative image of ethidium-bromidestained $1 \cdot 2 \%$ agarose gel showing control PCR reactions $(+$, mouse kidney RT CDNA without competomer, -, no template) and QCPCR assay lanes with fixed quantity of kidney RT-cDNA and varying dilutions, as shown, of $0.05 \mu \mathrm{g} / \mu \mathrm{l} \mathrm{ENaC} \alpha$ competomer. At the left, arrows indicate size of native (top) and competomer (bottom) mouse $\mathrm{ENaC} \alpha$ PCR products. At the right, numbers indicate Gibco 1 kb ladder. (B) Log/log plot using data from gel in panel A in linear regression ( $r=$ Pearson's correlation coefficient) to allow competomer dilution and moles of ENaC $\alpha$ (X-axes) corresponding to the product molar equivalence point $(Y$-axis $=0)$ to be determined (see Results).

using both regional densitometry of autoradiographs (Fig. 4.) and silver-grain counting of the emulsion-dipped sections in high magnification fields (Fig. 5). Sense control sections for all three $\mathrm{ENaC}$ subunits showed no specific hybridisation.

There were unequal levels of expression of $\mathrm{ENaC}$ subunit mRNA, such that $\alpha>\gamma \approx \beta$. ENaC subunit
mRNAs were expressed in both the cortex and medulla. Expression density was high, in a punctate distribution, in renal cortex for all three subunits. Emulsion-dipped slides revealed a pattern of expression suggesting that the cortical expression was confined to the distal nephron, involving the cortical collecting duct and adjacent distal tubule. In outer medulla, all subunits were expressed. Preliminary 
Table 3 Physiological parameters of mouse experimental treatment groups

Group

\begin{tabular}{|c|c|c|c|c|c|}
\hline & $\begin{array}{l}1 \\
(n=5)\end{array}$ & $\begin{array}{l}2 \\
(n=6)\end{array}$ & $\begin{array}{l}3 \\
(n=6)\end{array}$ & $\begin{array}{l}4 \\
(n=6)\end{array}$ & 5 and 6 \\
\hline Treatment & Adrenalectomy & Dexamethasone & Aldosterone & Spironolactone & Control \\
\hline Plasma renin activity $†$ & $4 \cdot 73 \pm 0.53$ & $3 \cdot 42 \pm 0 \cdot 39$ & $1 \cdot 55^{\star} \pm 0 \cdot 46$ & $4 \cdot 74 \pm 0 \cdot 93$ & $3 \cdot 80 \pm 0 \cdot 50$ \\
\hline Plasma aldosterone (pmol/l) & $<400^{*} \pm<110$ & $1870 \pm 200$ & $4660 \S \pm 120$ & $3140 \S \pm 690$ & $1980 \pm 240$ \\
\hline Plasma corticosterone $(\mathrm{nmol} / \mathrm{l})$ & $<55 \ddagger$ & $114 \ddagger \pm 45$ & $432 \pm 54$ & $470 \pm 63$ & $409 \pm 46$ \\
\hline Urine $\mathrm{Na}^{+} / \mathrm{K}^{+}$ & $1 \cdot 07 \pm 0.38$ & $0 \cdot 55 \pm 0 \cdot 21$ & $0 \cdot 35 \pm 0 \cdot 13$ & $1 \cdot 08 \pm 0 \cdot 22$ & $0.64 \pm 0.09$ \\
\hline
\end{tabular}

†In ng ANGI generated per $\mathrm{ml}$ per hour.

*Lower than all other groups, $P<0 \cdot 01$; §groups 3 and $4>$ other groups: group $3 P<0 \cdot 005$, group $4 P<0 \cdot 05$; $\neq$ lower than all other groups, $P<0 \cdot 001$.

Group 1, $n=5$; groups $2-6, n=6$ each.

in situ studies in which mouse kidney was sectioned in multiple planes indicated that tubules expressing ENaC subunit mRNAs in medulla both continued into cortical medullary rays and, increasingly, converged and predominated in medulla moving towards the papilla. This pattern of expression was thus fully consistent with expression in the medullary collecting duct. ENaC expression in renal medulla of other species (including rat (Duc et al. 1994))

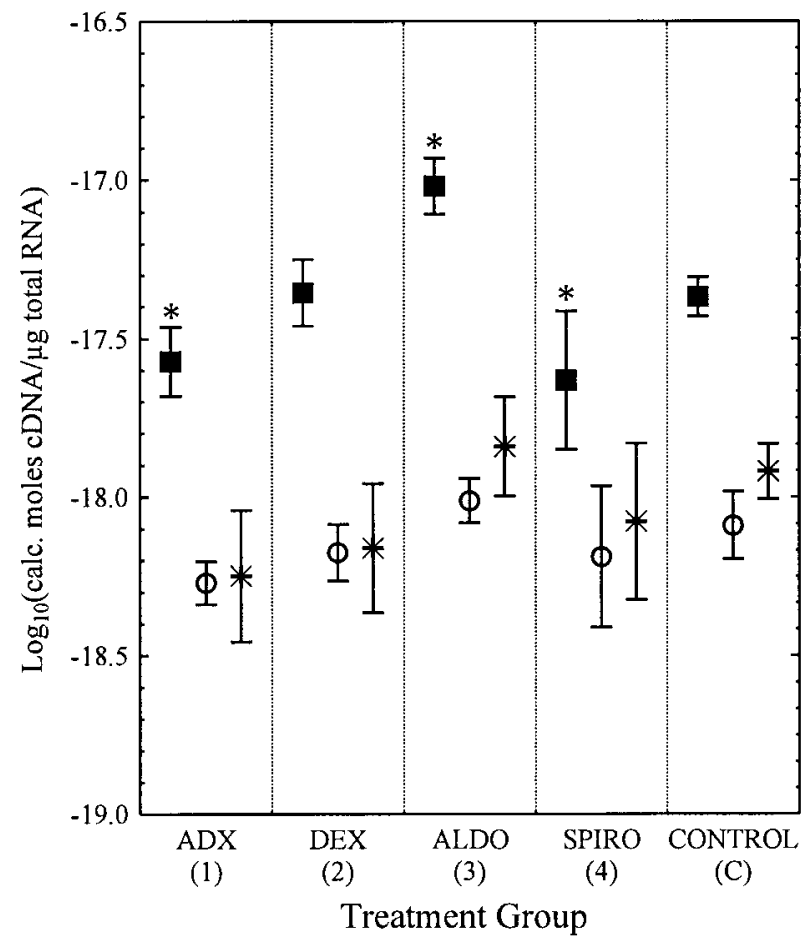

Figure 2 Levels of expression of $\mathrm{ENaC}$ subunit transcripts in mouse kidney by QCPCR. Treatment groups as in Table 1: group 1, $n=5$; groups $2-4, n=6$ each; group $C$ (controls, groups 5 and 6 combined), $n=6+6$. ADX, adrenalectomised; DEX, dexamethasone; ALDO, aldosterone; SPIRO, spironolactone. $Y$-axis values were derived as in Fig. 1, and are means \pm S.E. $\mathbf{\square}, \mathrm{ENaC} \alpha$; $\mathrm{O}, \mathrm{ENaC} \beta$; $*$, $\mathrm{ENaC} \gamma .{ }^{*} \mathrm{P}<0 \cdot 03$, group 3 compared with groups 1 and 4. has been shown to be in collecting duct, as physiological studies have always predicted.

There was little change in the level of expression of $\mathrm{ENaC} \beta$ and $\gamma$ across the outer medulla. Because of the convergence of collecting ducts in the medulla, autoradiographs of $\mathrm{ENaC} \beta$ and $\gamma$ had a lower expression density in the outer than in the inner stripe of the outer medulla. For $\mathrm{ENaC} \alpha$, highly expressing tubules were visible entering from the cortex and continuing into the outer medulla, where there was a greater background hybridisation. With aldosterone treatment (group 3), ENaC $\alpha$ mRNA expression also remained high across the full outer medulla. However, in the other groups, a sharp decline in collecting duct ENaC $\alpha$ mRNA expression occurred before the transition to inner stripe (Fig. 3, compare $\alpha$ with $\alpha+$ aldo), where the ducts were less clearly delineated than with in situ hybridisation for $\beta$ or $\gamma$ subunits (Figs 5, 6).

$\mathrm{ENaC}$ subunit mRNAs showed marked differences of expression in the inner medulla. ENaC $\beta$ mRNA expression continued down to the papillary collecting duct at only a slightly reduced expression density. ENaC $\gamma$ mRNA expression also continued into the inner medulla, but then reduced abruptly to undetectable levels before the terminal one-third of the inner medulla. ENaC $\alpha$ mRNA expression decreased to undetectable levels at the distal margin of the outer medulla to leave an abrupt boundary, with inner medulla lacking any significant $\mathrm{ENaC} \alpha$ mRNA expression (Fig. 6A).

Quantitative analysis of autoradiographs (Fig. 4) confirmed that the expression density was very similar for $\mathrm{ENaC} \beta$ and $\gamma$ in all groups, but was significantly $(P<0 \cdot 0002)$ greater for $\mathrm{ENaC} \alpha$, by a mean $2 \cdot 2$-fold $(1 \cdot 75-2 \cdot 8, \pm 1.96($ S.E. $))$ and $2 \cdot 0$-fold $(1 \cdot 65-2 \cdot 4)$ respectively. Figure 4 also illustrates that $\mathrm{ENaC} \alpha \mathrm{mRNA}$ expression was found to be significantly upregulated by aldosterone compared with that in all other groups in all regions. Changes across treatment groups in $\mathrm{ENaC} \beta$ and $\gamma$ were smaller, were related to relatively greater expression in response to aldosterone treatment, and were largely confined to the cortex in $\mathrm{ENaC} \beta$; there was a difference between aldosterone and adrenalectomy groups for 


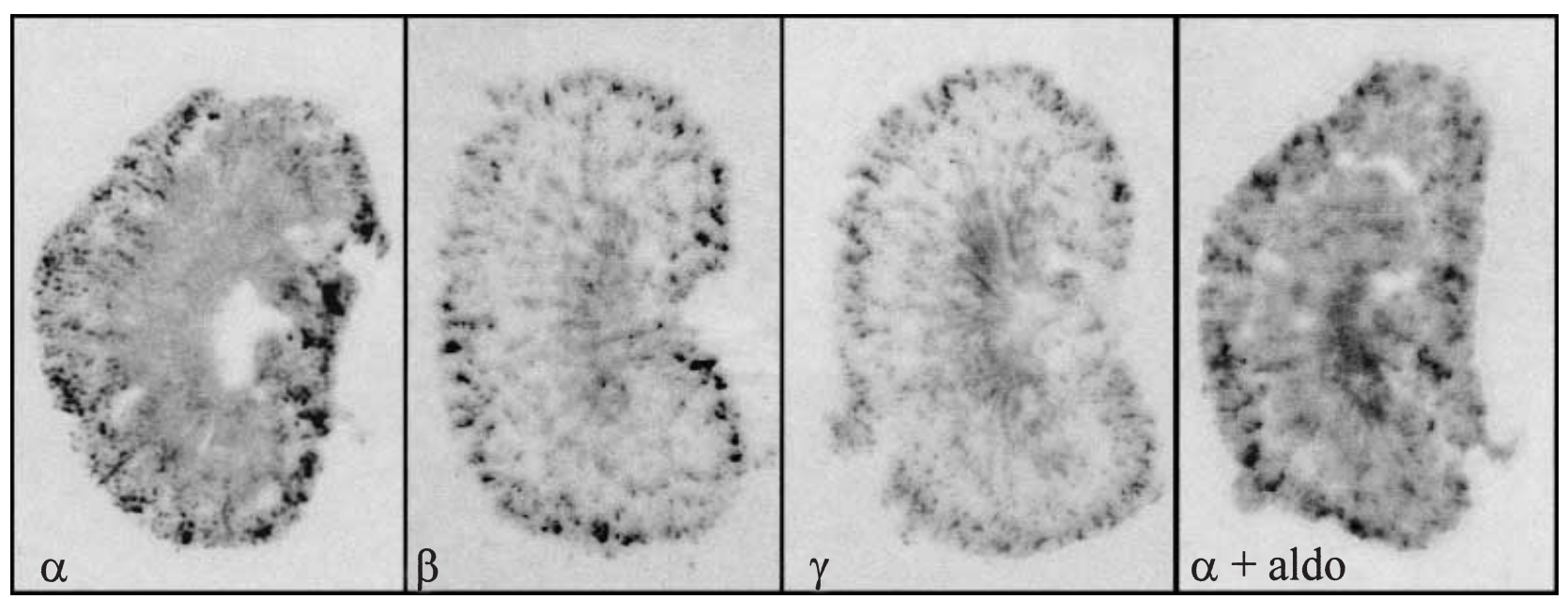

Figure 3 In situ hybridisation for $\mathrm{ENaC}$ subunits in mouse kidney. Autoradiographs (greatest expression shown as black) of mouse whole-kidney sections hybridised with ${ }^{35} \mathrm{~S}$ probes. $\alpha, \beta$ and $\gamma$, corresponding $\mathrm{ENaC}$ subunits in control group mouse kidney; $\alpha+$ aldo, $\mathrm{ENaC} \alpha$ in a group 3 (aldosterone treatment) mouse kidney. In $\alpha$, note that the highly expressing regions in cortex and outermost medulla give way, more centrally, to lower expression (uniform mid-grey) before the inner stripe, with expression decreasing to background (pale grey) on reaching the inner medulla in the centre. In $\beta$ and $\gamma$, note the 'tracks' consistent with expression in outer medullary collecting ducts converging centrally to the darker inner stripe. In $\alpha+$ aldo, note that the aldosterone upregulation of expression in the outer medulla results in the appearance of an $\mathrm{ENaC} \alpha$ pattern of expression with superimposed converging 'tracks', consistent with the upregulation in outer medullary collecting duct. For detail of inner stripe/inner medulla, see Fig. 6.
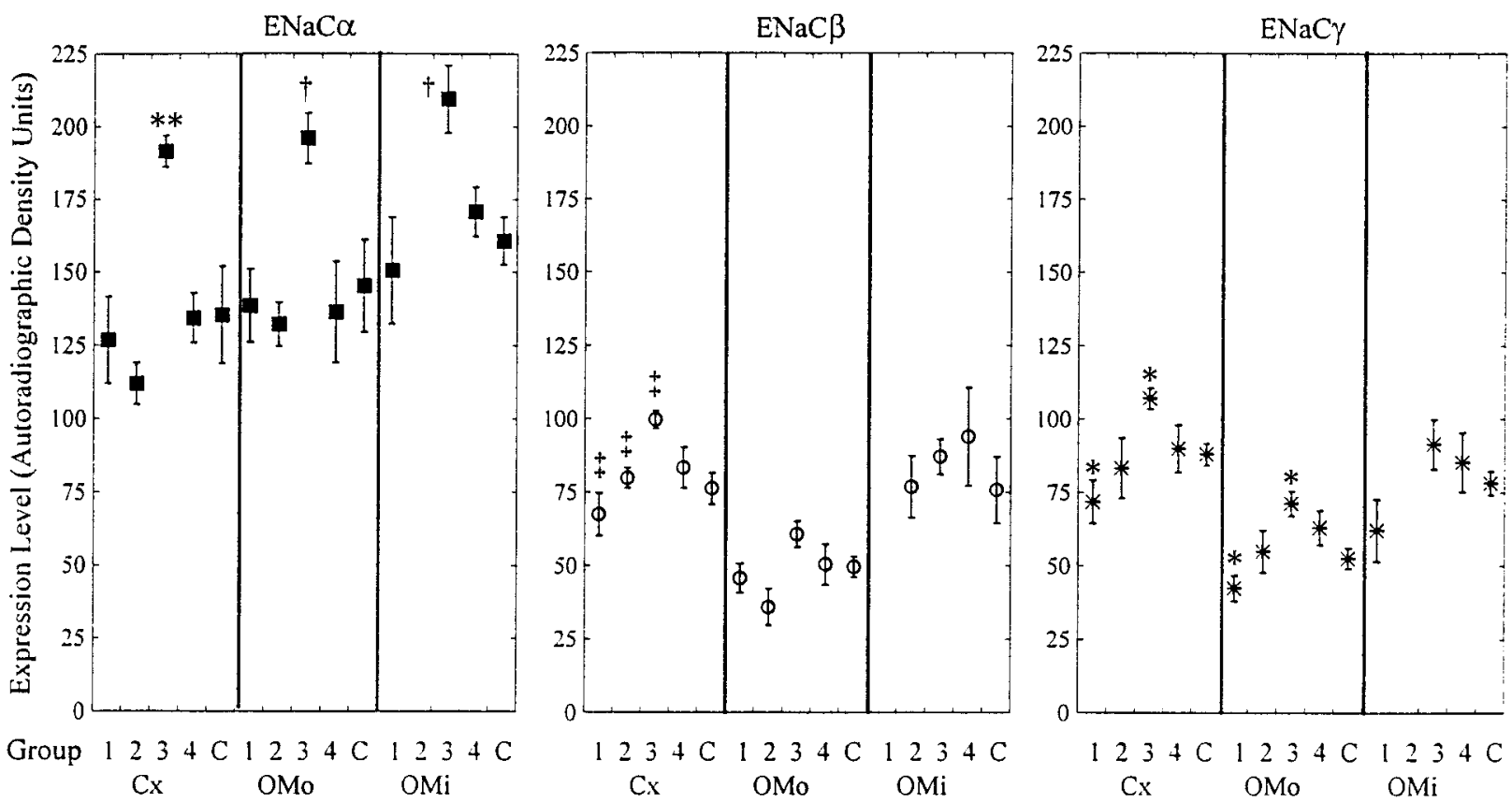

Figure 4 Regional densitometric analysis of in situ hybridisation for ENaC subunit mRNAs in mouse kidney. Treatment groups as in Table 1: group 1, $n=5$; groups 2-4, $n=6$ each; group C (controls, groups 5 and 6 combined), $n=6+6$. Because of convergence of collecting ducts traversing medulla, expression density is lower in the outer (OMo) than the inner (OMi) stripe of outer medulla. This effect is clearer for $\beta$ and $\gamma$ than for $\alpha$ (greater diffuse background; see text). Cx, cortex. Significant differences (within each vertical box) between group 3 and: ${ }^{* *}$ other groups $(P<0 \cdot 01)$; tother groups $(P<0 \cdot 05)$; fgroups 1 and $2(P<0 \cdot 05)$; ${ }^{*}$ group $1(P<0 \cdot 05)$. 


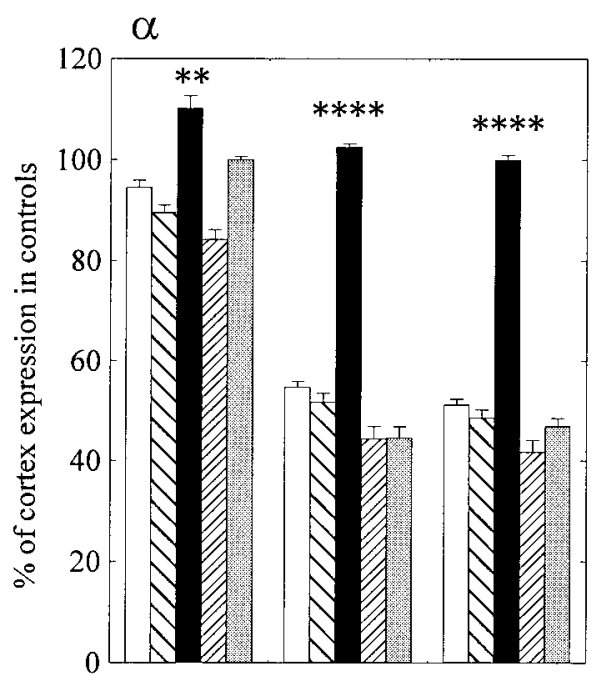

Region: $\quad \mathrm{Cx}$

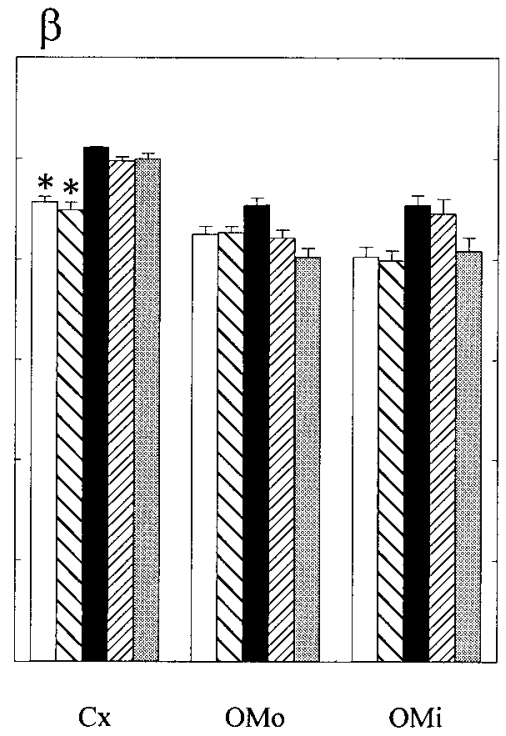

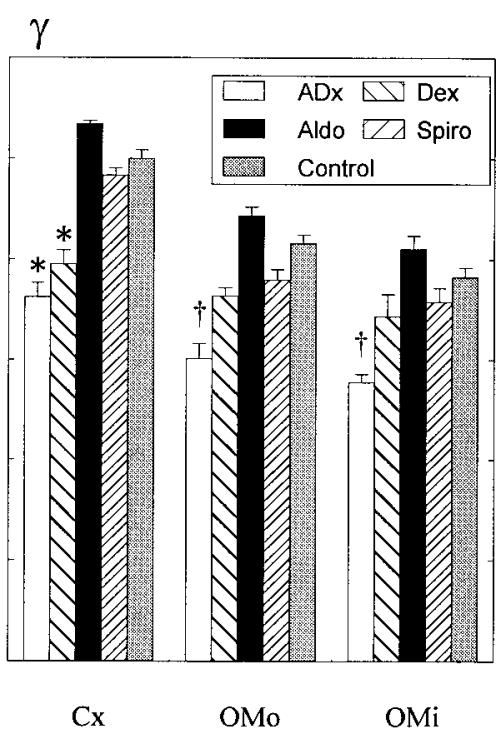

Figure 5 Analysis by silver-grain counting of in situ hybridisation for ENaC subunit mRNAs in mouse kidney. Treatment groups as in Table 1: group 1, $n=5$; groups 2-4, $n=6$ each; group $C$ (controls, groups 5 and 6 combined), $n=6+6$. Each plot illustrates trends 'across the distal nephron' for a probe and treatment group normalised to $100 \%$ as the expression of that probe in the cortex of controls. Cx, cortex; OMo, outer stripe of outer medulla; OMi, inner stripe of outer medulla. For expression of mRNAs of all subunits in all groups, $\mathrm{Cx}>\mathrm{OM}$ $(P<0.05)$, except $\alpha$ in group 3, and $\beta$ and $\gamma$ in groups 1 and 2. ADx, adrenalectomised; Dex, dexamethasone; Aldo, aldosterone; Spiro, spironolactone. ENaCa: ${ }^{* *}$ group 3 compared with groups 2 and $4, P<0 \cdot 01 ;{ }^{* * * *}$ group 3 compared with other groups, $P<0 \cdot 0005$. ENaC $\gamma$ and $\beta$ : * groups 1 and 2 compared with other groups, $P<0 \cdot 05$. ENaC $\gamma$ : tgroup 1 compared with controls and group $3, P<0 \cdot 05$.

$\mathrm{ENaC} \gamma$. The adrenalectomy group showed the lowest $\mathrm{ENaC} \gamma$ mRNA expression in all regions, being significantly less than that in the aldosterone-treated groups in cortex and outer stripe.

In situ hybridisation analysis, by silver-grain counting at high magnification, concentrated on a sector of each section within which the more highly expressing tubules were analysed in the cortex and outer medulla. Results presented in Fig. 5 illustrate the trends 'across the distal nephron' from cortex to inner stripe of outer medulla (Fig. 6 illustrates findings in inner medulla). First, it is clear from Fig. 5 that the level of expression universally declines from cortex to outer medulla, for all subunits in all groups. This decline is especially steep $(-46.5 \pm 9 \%)$ and significant $(P<0 \cdot 0005)$ for $\mathrm{mRNAs}$ of $\mathrm{ENaC} \alpha$, with the conspicuous exception of the aldosterone group, in which the change is less than $10 \%$, indicating very substantial upregulation of the $\mathrm{ENaC} \alpha$ mRNA level in outer medulla by aldosterone, as further shown in Fig. 6 (compare $\mathrm{B} \alpha$ with $\mathrm{A} \alpha$ ). The degree of cortico-medullary decline in $\mathrm{ENaC} \beta$ and $\gamma$ was less than in $\mathrm{ENaC} \alpha$; moreover, there was no significant decline for $\beta$ or $\gamma$ in either the adrenalectomy or the dexamethasone group. In these groups, cortical $\mathrm{ENaC} \beta$ and $\gamma$ mRNAs were reduced significantly $(P<0 \cdot 02)$ compared with cortical expression in other groups. The decline in $\mathrm{ENaC} \gamma \mathrm{mRNA}$ in the adrenalectomy group was particularly marked, and extended into the outer medulla $(P<0 \cdot 02$, adrenalectomy compared with aldosterone and controls), thus mirroring the $\mathrm{ENaC} \gamma$ expression density that was least in autoradiographs of the adrenalectomy group.

\section{Discussion}

The expression, in mouse kidney, of ENaC subunit mRNAs and their regulation by corticosteroids has not been studied in detail previously, despite the increasing use of this species in transgenic studies. In mouse, we found all three subunit mRNAs distributed in a pattern suggesting expression in distal tubule through to outer medullary collecting duct. Thus these regions have the potential to make fully functional amiloride-sensitive sodium channels. Initial studies in rat found $\mathrm{ENaC}$ subunit mRNA and protein to be expressed from distal tubule to outer medullary collecting duct, without expression in the inner medulla (Duc et al. 1994). A more recent study, using rat nephron microdissection, revealed a similar mRNA distribution (Vehaskari et al. 1998). Our finding that expression of $\mathrm{ENaC}$ subunit mRNAs in the mouse also extends into the inner medulla (in a pattern fully consistent with inner medullary collecting duct expression) was unexpected. Interestingly, a recent study involving northern blots of dissected regions of rat kidney suggested similar ENaC mRNA subunit expression in inner medulla (Stokes \& Sigmund 1998). 
A

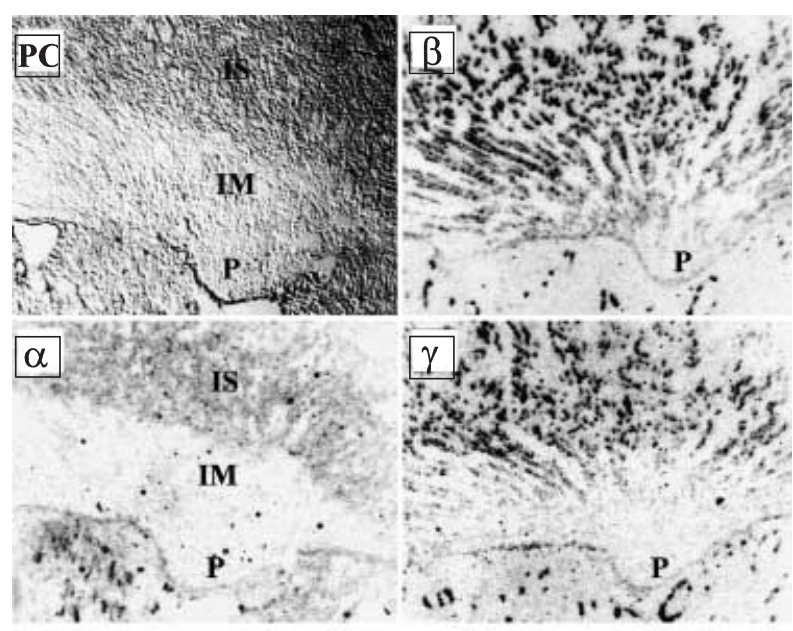

B

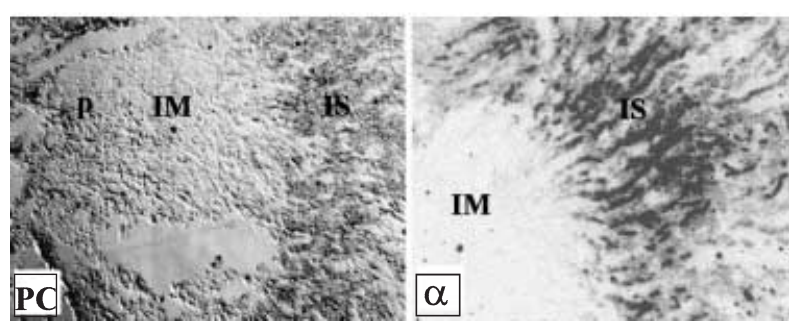

Figure 6 Detailed analysis of ENaC subunit mRNA expression in mouse renal medulla. (A) Control group kidney imaging by phase contrast microscopy (PC) or negative image of dark-field view (black=high expression) at $\times 50$ of in situ hybridisation for mouse $\mathrm{ENaC}$ subunits $(\alpha, \beta$ and $\gamma$ ) on adjacent sections. (B) Aldosterone treatment group kidney by phase contrast (PC) and $\mathrm{ENaC} \alpha$ in situ hybridisation. IS, inner stripe of outer medulla; IM, inner medulla; $P$, papilla. Note the very different pattern of expression of subunits in inner medulla $(\alpha, \beta$ and $\gamma$ in $(\mathrm{A}))$ and the strong upregulation of $\mathrm{ENaC} \alpha$ by aldosterone in outer medulla up to the boundary with inner medulla (compare $\mathrm{A} \alpha$ with $\mathrm{B} \alpha$ ).

The most striking regulatory effect found was that aldosterone significantly upregulated $\mathrm{ENaC} \alpha$ mRNA, particularly in the outer medulla (Figs 5, 6B) and by QcPCR for whole kidney. The major effect was one of upregulation by aldosterone excess, rather than downregulation by spironolactone and adrenalectomy. This is the first such study of $\mathrm{ENaC}$ regulation in mouse. Previous work has examined kidney expression of $\mathrm{ENaC}$ in the rat (Renard et al. 1995, Volk et al. 1995, Asher et al. 1996, Escoubet et al. 1997, Stokes \& Sigmund 1998), with modest upregulation of $\mathrm{ENaC} \alpha$ being reported. However, mineralocorticoid doses used in those rat studies were largely in the pharmacological range (5- to 15-fold greater) (Renard et al. 1995, Volk et al. 1995, Asher et al. 1996, Stokes \& Sigmund 1998). In the present study, an upregulation of the level of $\mathrm{ENaC} \alpha \mathrm{mRNA}$ of equal degree was seen across physiological changes in circulating aldosterone. All results point to this effect being exerted via mineralocorticoid receptor.

In mice, we found aldosterone caused lesser, but significant, increases in the level of mRNA for $\mathrm{ENaC} \beta$ in cortex, and of $\mathrm{ENaC} \gamma \mathrm{mRNA}$, compared with adrenalectomy. Previous studies have found no clear corticosteroid regulation of $\mathrm{ENaC} \beta$ or $\gamma$ in rat kidney (Renard et al. 1995, Asher et al. 1996, Escoubet et al. 1997, Stokes \& Sigmund 1998). These effects on $\mathrm{ENaC} \gamma$, and especially $\beta$, mRNA expression were relatively small and limited to specific renal regions, and thus would probably not have been seen in analyses of the whole kidney. Moreover, previous studies examining the effects of corticosteroid were of shorter duration and there is evidence, in A6 kidney cells (Middleton et al. 1998) (and rat colon (Escoubet et al. 1997)) that ENaC $\beta$ and $\gamma$ mRNA changes may develop over at least several days. These differences may explain the lack of significant changes in renal $\mathrm{ENaC} \beta$ or $\gamma$ expression in previous in vivo studies. $\mathrm{ENaC} \gamma$ mRNA levels respond to corticosteroids in rabbit cortical collecting duct cells in culture (Denault et al. 1996). However, as the magnitude of the changes in $\mathrm{ENaC} \beta$ and $\gamma$ mRNA reported above are particularly small, they should be regarded more cautiously unless confirmed by other research.

Past research has also looked at the effects of dexamethasone on renal $\mathrm{ENaC}$ in rats, and most (Volk et al. 1995, Asher et al. 1996), but not all (Renard et al. 1995), studies have shown upregulation of renal $\mathrm{ENaC} \alpha \mathrm{mRNA}$. This effect appears related to high glucocorticoid receptor occupancy, rather than downregulation of physiological glucocorticoid levels with the HPA axis, and is mimicked by the pure glucocorticoid receptor agonist, RU28362, at high dosage (Stokes \& Sigmund 1998). The dose of dexamethasone used in our study was more than 10-fold lower and, although this dose strongly downregulated the HPA axis, as expected (Almeida et al. 1997), there was little influence on $\mathrm{ENaC}$ mRNA expression. In vitro physiological glucocorticoids bind mineralocorticoid receptor with an affinity equal to that of aldosterone, and circulate in 100-1000-fold excess over aldosterone. However, the potent glucocorticoid-inactivating enzyme,

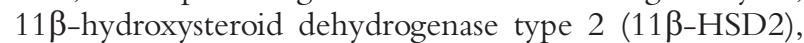
prevents these circulating physiological glucocorticoids from influencing $\mathrm{ENaC}$ expression, by preventing their access to the mineralocorticoid receptor (and glucocorticoid receptor) in aldosterone target cells in which $\mathrm{ENaC}$ is expressed. This $11 \beta-\mathrm{HSD} 2$ barrier provides an explanation as to why suppression of physiological glucocorticoids in the circulation by the relatively low dose of dexamethasone in our group 2 mice had little effect on renal $\mathrm{ENaC}$ subunit transcription. As considerably greater doses of dexamethasone upregulate $\mathrm{ENaC} \alpha$, this suggests that bypassing of $11 \beta-\mathrm{HSD} 2$ to increase the 
occupancy of glucocorticoid receptors can upregulate $\mathrm{ENaC} \alpha$.

ENaC subunit mRNAs are expressed at different levels in whole kidney, with $\alpha>\gamma \approx \beta$. Our estimate of the relative excess of $\mathrm{ENaC} \alpha$ is slightly greater for whole kidney with QcPCR than from in situ hybridisation with whole-section densitometry. However, the ratios over which the two different estimates overlap are the best overall estimates, giving an excess of $\alpha$ over $\beta$ and $\gamma$ of $1 \cdot 75$ - to $2 \cdot 8$ - and $1 \cdot 95$ - to $2 \cdot 4$-fold, respectively. ENaC in collecting duct probably has the composition $\alpha 2 \beta \gamma$ (Firsov et al. 1998, Kosari et al. 1998), and the relative subunit mRNA abundance in mouse kidney fits well with this stoichiometry. The relative channel activities of $\alpha \beta$, $\alpha \gamma$ and $\alpha \beta \gamma$ are 3- to 5-, 3- to 5- and 100-fold more active than that of $\mathrm{ENaC} \alpha$ expression alone (Canessa et al. 1994, Garty \& Palmer 1997, Berdiev et al. 1998). In controls, a disproportionately low level of $\mathrm{ENaC} \alpha \mathrm{mRNA}$ in outer medullary collecting duct (Fig. 5) indicated that the $\mathrm{ENaC} \alpha$ subunit supply for $\alpha 2 \beta \gamma$ channels is more likely to be limiting than it is in cortex. Thus the particularly marked $\mathrm{ENaC} \alpha$ mRNA upregulation in outer medulla (Figs 5, 6B) may be multiplied to a more significant change in channel conductance.

In mouse inner medulla, we found no significant expression of ENaC $\alpha$ mRNA. Expression of ENaC $\beta \gamma$ alone produces no functional sodium-channel activity (Canessa et al. 1994). Upregulation of $\mathrm{ENaC} \alpha$ in inner medullary collecting duct would potentially translate to a dramatic effect on the inner medullary collecting duct capacity for selective sodium transport, as $\alpha 2 \beta \gamma \mathrm{ENaC}$ could then form. Stokes \& Sigmund (1998) have reported just such a finding in rats treated acutely with corticosteroids (larger doses than were used in the present study), and that such rat inner medullary collecting duct sodium channels have $\mathrm{ENaC}$ characteristics on patch clamping. Cation/sodium conductances atypical of $\mathrm{ENaC}$ have been reported in inner medullary collecting duct (Light et al. 1988, Benos et al. 1995, Garty \& Palmer 1997); although the genes involved are unknown, $\mathrm{ENaC}$ subunits could be participants. Certainly, the $\mathrm{ENaC} \delta$ subunit (Waldmann et al. 1995) or mammalian homologues of degenerins (e.g. in ASIC/DRASIC proton/cation channels (Chen et al. 1998, Snyder et al. 1998)), form functional cation channels in which $\mathrm{ENaC}$ subunits appear to be able to participate. Thus the presence of $\mathrm{ENaC} \beta \gamma$ (without $\alpha$ ) mRNA in inner medullary collecting duct (Fig. 6) raises the possibility of an alternative $\mathrm{ENaC}$ superfamily channel and, clearly, further studies on sodium conductance in the mouse inner medullary collecting duct would be of interest.

We have studied the chronic regulation of $\mathrm{ENaC}$ subunits at the steady-state mRNA level in detail in mouse kidney. The modest, 1.9- to 3.5-fold, induction of $\mathrm{ENaCa}$ mRNA that we observed, if 'amplified' by producing more favourable subunit stoichiometry, would account for a more significant proportion of the aldosterone upregulation of sodium transport. Our results in mouse suggest the possibility of this in outer medullary collecting duct in particular. Clearly, situations leading to $\mathrm{ENaC} \alpha$ upregulation in inner medullary collecting duct are also likely to result in significant increases in apical sodium conductance. However, in cortex, it seems particularly clear that transcriptional upregulation of, as yet unidentified, 'aldosterone-responsive genes' (Grunder \& Rossier 1997), rather than $\mathrm{ENaC}$ subunits, must produce the increased sodium resorption induced by aldosterone.

\section{Acknowledgements}

We thank the Medical Research Council (R W B is an MRC Clinician Scientist Fellow, grant G108/192), The Wellcome Trust (Wellcome Studentship EDI/012 to P M) and the Carnegie Foundation (Studentship held by S M M) for their support. We thank June Noble and Sharon Rossiter for their expert technical assistance, and Carina Hibbert for adapting the image analysis software. We thank Dr Chris Kenyon for his valuable advice and for his assistance with the plasma renin activity, aldosterone and corticosterone assays.

\section{References}

Almeida OFX, Canoine V, Ali S, Holsboer F \& Patchev VK 1997 Activational effects of gonadal steroids on hypothalamopituitary-adrenal regulation in the rat disclosed by response to dexamethasone suppression. Journal of Neuroendocrinology 9 129-134.

Asher C, Wald H, Rossier BC \& Garty H 1996 Aldosterone-induced increase in the abundance of $\mathrm{Na}^{+}$channel subunits. American Journal of Physiology 271 C605-C611.

Benos DJ, Awayda MS, Ismailov II \& Johnson JP 1995 Structure and function of amiloride-sensitive $\mathrm{Na}^{+}$channels. Journal of Membrane Biology 143 1-18.

Berdiev BK, Karlson KH, Jovov B, Ripoll PJ, Morris R, LoffingCueni D, Halpin P, Stanton BA, Kleyman TR \& Ismailov II 1998 Subunit stoichiometry of a core conduction element in a cloned epithelial amiloride-sensitive $\mathrm{Na}^{+}$channel. Biophysical Journal 75 2292-2301.

Brown RW, Chapman KE, Kotelevtsev Y, Yau JLW, Lindsay RS, Brett L, Leckie C, Murad P, Lyons V, Mullins JJ, Edwards CRW \& Seckl JR 1996 Cloning and production of antisera to human placental 11beta-hydroxysteroid dehydrogenase type 2. Biochemical Journal 313 1007-1017.

Canessa CM, Schild L, Buell G, Thorens B, Gautschi I, Horisberger J-D \& Rossier BC 1994 Amiloride-sensitive epithelial $\mathrm{Na}^{+}$channel is made of three homologous subunits. Nature 367 463-467.

Chang SS, Grunder S, Hanukoglu A, Rosler A, Mathew PM, Hanukoglu I, Schild L, Lu Y, Shimkets RA, NelsonWilliams C, Rossier BC \& Lifton RP 1996 Mutations in subunits of the epithelial sodium channel cause salt wasting with hyperkalaemic acidosis, pseudohypoaldosteronism type 1. Nature Genetics 12 248-253.

Chen CC, England S, Akopian AN \& Wood JN 1998 A sensory neuron-specific, proton-gated ion channel. Proceedings of the National Academy of Sciences of the USA 95 10240-10245.

Chomczynski P \& Sacchi N 1987 Single-step method of RNA isolation by acid guanidinium thiocyanate-phenol-chloroform extraction. Analytical Biochemistry 162 156-159. 
Clackson T, Gussow D \& Jones PT 1991 General application of PCR to gene cloning and manipulation. In PCR 1: A Practical Approach, pp 187-210. Eds MJ McPherson, P Quirke \& GR Taylor. Oxford: IRL Press.

Denault DL, FejesToth G \& NarayFejesToth A 1996 Aldosterone regulation of sodium channel gamma-subunit mRNA in cortical collecting duct cells. American Journal of Physiology 271 C423-C428.

Duc C, Farman N, Canessa CM, Bonvalet J \& Rossier BC 1994 Cell-specific expression of epithelial sodium channel alpha, beta, and gamma subunits in aldosterone-responsive epithelia from the rat: localization by in situ hybridization and immunocytochemistry. Journal of Cell Biology 127 1907-1921.

Escoubet B, Coureau C, Bonvalet J \& Farman N 1997 Noncoordinate regulation of epithelial $\mathrm{Na}$ channel and $\mathrm{Na}$ pump subunit mRNAs in kidney and colon by aldosterone. American Journal of Physiology 272 C1482-C1491.

Firsov D, Gautschi I, Merillat AM, Rossier BC \& Schild L 1998 The heterotetrameric architecture of the epithelial sodium channel (ENac). EMBO Journal 17 344-352.

Garty H \& Palmer LG 1997 Epithelial sodium channels: function, structure and regulation. Physiological Reviews 77 359-396.

Grunder S \& Rossier BC 1997 A reappraisal of aldosterone effects on the kidney: new insights provided by epithelial sodium channel cloning. Current Opinion in Nephrology and Hypertension 6 35-39.

Hall LL, Bicknell GR, Primrose L, Pringle JH, Shaw JA \& Furness PN 1998 Reproducibility in the quantification of mRNA levels by RT-PCR-ELISA and RT competitive-PCR-ELISA. Biotechniques 24 652-658.

Hansson JH, NelsonWilliams C, Suzuki H, Schild L, Shimkets R, Lu Y, Canessa C, Iwasaki T, Rossier B \& Lifton RP 1995

Hypertension caused by a truncated epithelial sodium channel gamma subunit: genetic heterogeneity of Liddle syndrome. Nature Genetics 11 76-82.

Hummler E, Barker P, Talbot C, Wang Q, Verdumo C, Grubb B, Gatzy J, Burnier M, Horisberger JD, Beermann F, Boucher R \& Rossier BC 1997 A mouse model for the renal salt-wasting syndrome pseudohypoaldosteronism. Proceedings of the National Academy of Sciences of the USA 94 11710-11715.

Kemendy AE, Kleyman TR \& Eaton DC 1992 Aldosterone alters the open probability of amiloride-blockable sodium channels in A6 epithelia. American Journal of Physiology 263 C825-C837.

Kosari F, Sheng SH, Li JQ, Mak DOD, Foskett JK \& Kleyman TR 1998 Subunit stoichiometry of the epithelial sodium channel. Journal of Biological Chemistry 273 13469-13474.

Kotelevtsev Y, Holmes MC, Burchell A, Houston PM, Schmoll D, Jamieson P, Best R, Brown R, Edwards CRW, Seckl JR \& Mullins JJ 1997 11Beta-hydroxysteroid dehydrogenase type 1 knockout mice show attenuated glucocorticoid-inducible responses and resist hyperglycemia on obesity or stress. Proceedings of the National Academy of Sciences of the USA 94 14924-14929.

Light DB, McCann FV, Keller TM \& Stanton BA 1988 Amiloride-sensitive cation channel in apical membrane of inner medullary collecting duct. American Journal of Physiology $\mathbf{2 5 5}$ F278-F286.

Middleton P, Al-Khalili O, Zuckerman J, Rokaw MD, Johnson JP \& Eaton DC 1998 Beta-ENaC mRNA and protein levels increase in
A6 cells following long-term but not short-term exposure to aldosterone. FASEB Journal 125683 (Abstract).

Millar JA, Leckie BJ, Morton JJ, Jordan J \& Tree M 1980 A micro assay for active and total renin concentration in human plasma based on antibody trapping. Clinica et Chimica Acta 101 5-15.

Pacha J, Frindt G, Antonian L, Silver RB \& Palmer LG 1993 Regulation of $\mathrm{Na}$ channels of the rat cortical collecting tubule by aldosterone. Journal of General Physiology 102 25-42.

Park F, Koike G \& Cowley AW Jr 1998 Regional time-dependent changes in vasopressin $\mathrm{V} 2$ receptor expression in the rat kidney during water restriction. American Journal of Physiology 274 F906-F913.

Piatak M Jr, Luk K, Williams B \& Lifson JD 1993 Quantitative competitive polymerase chain reaction for accurate quantitation of HIV DNA and RNA species. Biotechniques 14 70-76, 78-80.

Renard S, Voilley N, Bassilana F, Lazdunski M \& Barbry P 1995 Localization and regulation by steroids of the alpha, beta and gamma subunits of the amiloride-sensitive $\mathrm{Na}^{+}$channel in colon, lung and kidney. Pfluegers Archiv 430 299-307.

Snyder PM, Price MP, McDonald FJ, Adams CM, Volk KA, Zeiher BG, Stokes JB \& Welsh MJ 1995 Mechanism by which Liddle's syndrome mutations increase activity of a human epithelial $\mathrm{Na}^{+}$ channel. Cell 83 969-978.

Snyder PM, Cheng C, Prince LS, Rogers JC \& Welsh MJ 1998 Electrophysiological and biochemical evidence that DEG/ENac cation channels are composed of nine subunits. Journal of Biological Chemistry 273 681-684.

Stokes JB \& Sigmund RD 1998 Regulation of reENaC mRNA by dietary $\mathrm{NaCl}$ and steroids: organ, tissue, and steroid heterogeneity. American Journal of Physiology 43 C1699-C1707.

Vallet V, Chraibi A, Gaeggeler H, Horisberger J \& Rossier BC 1997 An epithelial serine protease activates the amiloride-sensitive sodium channel. Nature 389 607-610.

Vehaskari VM, Hempe JM, Manning J, Aviles DH \& Carmichael MC 1998 Developmental regulation of $\mathrm{ENaC}$ subunit mRNA levels in rat kidney. American Journal of Physiology 43 C1661-C1666.

Volk KA, Sigmund RD, Snyder PM, McDonald FJ, Welsh MJ \& Stokes JB $1995 \mathrm{RENaC}$ is the predominant $\mathrm{Na}^{+}$channel in the apical membrane of the rat renal inner medullary collecting duct. Journal of Clinical Investigation 96 2748-2757.

Waldmann R, Champigny G, Bassilana F, Voilley N \& Lazdunski M 1995 Molecular cloning and functional expression of a novel amiloride-sensitive $\mathrm{Na}^{+}$channel. Journal of Biological Chemistry 270 27411-27414.

Wilkinson DG 1992 In Situ Hybridisation: A Practical Approach. Oxford: IRL Press.

Zhang JL \& Byrne CD 1999 Differential priming of RNA templates during cDNA synthesis markedly affects both accuracy and reproducibility of quantitative competitive reverse-transcriptase PCR. Biochemical Journal 337 231-241.

Received 1 June 1999

Revised manuscript received 20 October 1999 Accepted 25 November 1999 